\title{
Inhibitory action of bisphosphonates on bone resorption does not involve the regulation of RANKL and OPG expression
}

\author{
Yong Hee Kim, Gwan-Shik Kim, and Jeong- \\ Hwa Baek ${ }^{1}$ \\ Department of Pharmacology and Dental Therapeutics, College of \\ Dentistry, Seoul National University, Seoul, Korea \\ ${ }^{1}$ Corresponding author: Tel, +82-2-740-8689; \\ Fax, +82-2-741-3193; E-mail, baekjh@snu.ac.kr
}

Accepted 9 May 2002

Abbreviations: RANKL, Receptor Activator of Nuclear Factor kB Ligand; OPG, Osteoprotegerin; TRAP, tartrate-resistant acid phosphatase; VNR, vitronectin receptor; CTR, calcitonin receptor; RT$P C R$, reverse transcription-polymerase chain reaction; OCLS, osteoclast-like cells; $1,25-(\mathrm{OH})_{2} \mathrm{VitD}_{3}, 1,25$-dihydroxyvitamin $\mathrm{D}_{3}$

\begin{abstract}
The mechanism of inhibitory action of bisphosphonates on bone resorption is not fully elucidated. Osteoclast formation and activity are regulated by osteoblast-derived factors such as the osteoclast differentiating factor, receptor activator of NF-kappaB ligand (RANKL) and the inhibitor, osteoprotegerin (OPG). To investigate in vitro effects of bisphosphonates on mouse osteoblastic cells, we examined the expression levels of RANKL and OPG in the cells treated with alendronate or pamidronate $\left(10^{-8} \sim 10^{-5} \mathrm{M}\right)$ alone, or combined with $10 \mathrm{nM}$ of $1,25-(\mathrm{OH})_{2} \mathrm{Vit}_{3}$ for 24 or $48 \mathrm{~h}$. Various concentrations of alendronate and pamidronate did not change the mRNA expression of RANKL and OPG consistently irrespective of $1,25-(\mathrm{OH})_{2} \mathrm{Vit}_{3}$ presence. When added into cocultures of mouse osteoblastic cells and bone marrow cells, both alendronate and pamidronate inhibited osteoclast formation and bone resorption but failed to alter the RANKL and OPG mRNA expression. These results indicate that the inhibition of bone resorption by bisphosphonates is not mediated by the regulation of RANKL and OPG expression.
\end{abstract}

Key words: RANKL, OPG, alendronate, pamidronate, osteoclastogenesis

\section{Introduction}

Bisphosphonates, stable analogs of pyrophosphate, are potent inhibitors of bone resorption and have been used as effective therapeutic agents for the management of osteoporosis and other bone diseases such as Paget's disease (Papapoulos, 1996; Rodan and Fleisch, 1996; Fleisch, 1997). Osteoclasts, derived from hematopoietic precursors of monocyte/macrophage lineage, are primary bone resorbing cells and play a pivotal role in normal and pathologic bone remodeling in concert with osteoblasts (Roodman, 1996; Hayashi et al., 1998; Suda et al., 1999). Inhibition of bone resorption by bisphosphonates has been principally attributed to their inhibitory effect on osteoclasts. Bisphosphonates decrease the commitment of osteoclast progenitors into osteoclasts and osteoclast recruitment and promote apoptosis of mature osteoclasts (Hughes et al., 1989; Hughes et al., 1995; Parfitt et al., 1996; Jilka et al., 1998). In addition to direct effects on osteoclasts, it has been reported that bisphosphonates inhibit bone resorption indirectly through osteoblasts (Sahni et al., 1993; Nishikawa et al., 1996; Vitte et al., 1996; Plotkin et al., 1999). They have shown that bisphosphonates promote the release of factors from osteoblasts that inhibit the osteoclast formation and activity. The inhibitory factors released from bisphosphonate-treated osteoblasts, however, have not yet been identified.

RANKL, a member of the tumor necrosis factor (TNF) superfamily, is a membrane-bound protein produced by osteoblasts/stromal cells. It is known to be both sufficient and necessary for osteoclast formation in vitro in the presence of macrophage-colony stimulating factor (M-CSF) (Lacey et al., 1998; Quinn et al., 1998; Yasuda et al., 1998). Osteoprotegerin (OPG), a member of the TNF receptor superfamily, has been identified as a novel cytokine receptor secreted from osteoblasts (Simonet et al., 1997). OPG inhibits both differentiation and activation of osteoclasts by acting as a decoy receptor of RANKL (Lacey et al., 1998; Yasuda et al., 1998). It has been suggested that RANKL and OPG act as key mediators through which many osteotropic agents manifest their inhibitory or stimulatory effects on bone resorption (Suda et al., 1999; Takahashi et al., 1999; Aubin and Bonnelye, 2000; Hofbauer et al., 2000).

Here we examined whether the inhibitory effects of bisphosphonates on osteoclast formation and bone resorption is mediated through the regulation of RANKL and OPG expression in osteoblastic cells. Our results indicate that RANKL and OPG might not function as mediators of bisphosphonates action on bone resorption. 
Table I. Primer sequences used in semiquantitative RT-PCR.

\begin{tabular}{lll}
\hline Murine RANKL & Forward & $5^{\prime}$-ATCAGAAGACAGCACTCACT-3' \\
& Reverse & $5^{\prime}$-ATCTAGGACATCCATGCTAATGTTC-3' \\
Murine OPG & Forward & $5^{\prime}$-TGAGTGTGAGGAAGGGCGTTAC-3' \\
& Reverse & $5^{\prime}$-TTCCTCGTTCTCTCAATCTC-3' \\
Murine $\beta$-actin & Forward & $5^{\prime}$-GGACTCCTATGGTGGGTGACGAGG-3' \\
& Reverse & $5^{\prime}$-GGGAGAGCATAGCCCTCGTAGAT-3' \\
Murine tartrate-resistant acid & Forward & $5^{\prime}$-TGACAAGAGGTTCCAGGA-3' \\
phosphatase (TRAP) & Reverse & $5^{\prime}$-AGCCAGGACAGCTGAGTG-3' \\
Murine vitronectin receptor (VNR) & Forward & $5^{\prime}$-GCTCAGATGAGACTTTG-3 \\
& Reverse & $5^{\prime}$-ATCAACAATGAGCTGGA-3' \\
Murine calcitonin receptor (CTR) & Forward & $5^{\prime}$-GTGAAAAGGCGGAATCT-3' \\
& Reverse & $5^{\prime}$-AGGAACATGTGCTTGTG-3' \\
\hline
\end{tabular}

\section{Materials and Methods}

\section{Animals and reagents}

Newborn mice and 4-5 week-old mice, both ICR strain, were obtained from Daehan Bio Link (Eumsung, Choongchung, Korea). Neonatal mice were used for preparing osteoblastic cells and the latter were used for bone marrow cell cultures. The bisphosphonates, alendronate and pamidronate, were kindly provided from Merck \& Co (Rahway, NJ, USA) and Hallim Pharm (Seoul, Korea), respectively. DMEM, $\alpha$-MEM, fetal bovine serum (FBS), collagenase, Superscript ${ }^{\mathrm{TM}}$ First-Strand Synthesis System, and other culture reagents were purchased from Gibco-BRL (Grand Island, NY, USA). 1,25-(OH $)_{2} V_{i t D_{3}}$ was purchased from Calbiochem (La Jolla, CA, USA). easy-BLUE ${ }^{\text {TM }}$ reagent and TaKaRa $\mathrm{Taq}^{\mathrm{TM}}$ were purchased from iNtRON (Seoul, Korea) and TaKaRa (Otsu, Shiga, Japan), respectively. OAAS ${ }^{\mathrm{TM}}$ was obtained from OCT Inc. (Chunan, Chungnam, Korea). Leukocyte acid phosphatase assay kit was purchased from Sigma (St Louis, MO, USA).

\section{Osteoblastic cell culture}

Mouse osteoblastic cells were isolated from 30-40 neonatal ICR mice calvariae by enzymatic digestion as previously described (Kim et al. 1998). In brief, aseptically isolated frontal and parietal bones were digested with enzyme mixture $(0.1 \%$ collagenase, $0.05 \%$ trypsin and $0.5 \mathrm{mM}$ EDTA) for 10, 10, 10, 20, 20 , and 20 min each. Osteoblastic cells, which were released in the later periods, were seeded in $60 \mathrm{~mm}$ dish in $\alpha$-MEM containing $10 \%$ of FBS and $100 \mathrm{U} / \mathrm{ml}$ of penicillin and $100 \mu \mathrm{g} / \mathrm{ml}$ of streptomycin. Half million cells at the second passage were seeded in $60 \mathrm{~mm}$ dish and cultured for 2 days at $37^{\circ} \mathrm{C}$ in $95 \%$ humidified air plus $5 \% \mathrm{CO}_{2}$. Then, cells were treated with various concentrations of alendronate or pamidronate in the presence or absence of $1,25-(\mathrm{OH})_{2} \mathrm{VitD}_{3}$ for 24 or $48 \mathrm{~h}$.

\section{Osteoclast differentiation and bone resorption assay}

Bone marrow cells were prepared from tibiae and femurs from 4-5 week-old ICR mice by flushing bone marrow cavity with $\alpha$-MEM and lysing erythrocytes with $0.83 \%$ $\mathrm{NH}_{4} \mathrm{Cl}$ in $10 \mathrm{mM}$ Tris- $\mathrm{HCl} \mathrm{pH} \mathrm{7.4}$. To induce osteoclast formation in vitro, coculture of osteoblastic cells $\left(7.5 \times 10^{3}\right.$ cells/well) and bone marrow cells $\left(1.5 \times 10^{5}\right.$ cells/well) was performed in a 48-well plate coated with bone mineral-like apatite crystal (OAAS ${ }^{\mathrm{TM}}$ ). Cells were cultured in $0.3 \mathrm{ml}$ of $\alpha$-MEM containing $10 \%$ FBS and 10 $\mathrm{nM}$ of $1,25-(\mathrm{OH})_{2} \mathrm{VitD}_{3}$ for 6 days. The medium was changed every other day and bisphosphonates were added at the beginning of culture and at the time of medium change. At the end of the cultures, the cells were subjected to a tartrate-resistant acid phosphatase (TRAP) staining using leukocyte acid phosphatase assay kit following manufacturer's protocol. TRAPpositive multinucleated cells containing three or more nuclei were counted as osteoclast-like cells (OCLs). After counting the number of OCLs, the culture plate was washed twice with PBS and treated with $12 \%$ sodium hypochlorite to remove cells and resorption area was measured by using Global Lab image system (Data Translation Inc. Marlboro, MA, USA).

For reverse transcription-polymerase chain reaction (RTPCR), coculture was performed by using bone marrow cells $\left(3 \times 10^{6}\right.$ cells $)$ and mouse osteoblastic cells $\left(1.5 \times 10^{4}\right.$ cells). In the same culture condition as above, cells were cultured for indicated periods and lysed with easy-BLUE ${ }^{\mathrm{TM}}$ reagent for the isolation of total cellular RNA.

\section{Semiquantitative RT-PCR}

cDNA was synthesized from $1 \mu \mathrm{g}$ of total RNA by extension of random primers with $1 \mathrm{U}$ of Superscript RT. PCR was performed in a final volume of $50 \mu$ containing $2 \mathrm{U}$ of Takara Taq, $1 \times$ PCR buffer, $0.8 \mathrm{mM}$ dNTP mixture, and $100 \mathrm{pM}$ of specific primers. The reactions were: denaturation at $95^{\circ} \mathrm{C}$ for $30 \mathrm{~s}$, annealing at $53^{\circ} \mathrm{C}$ 

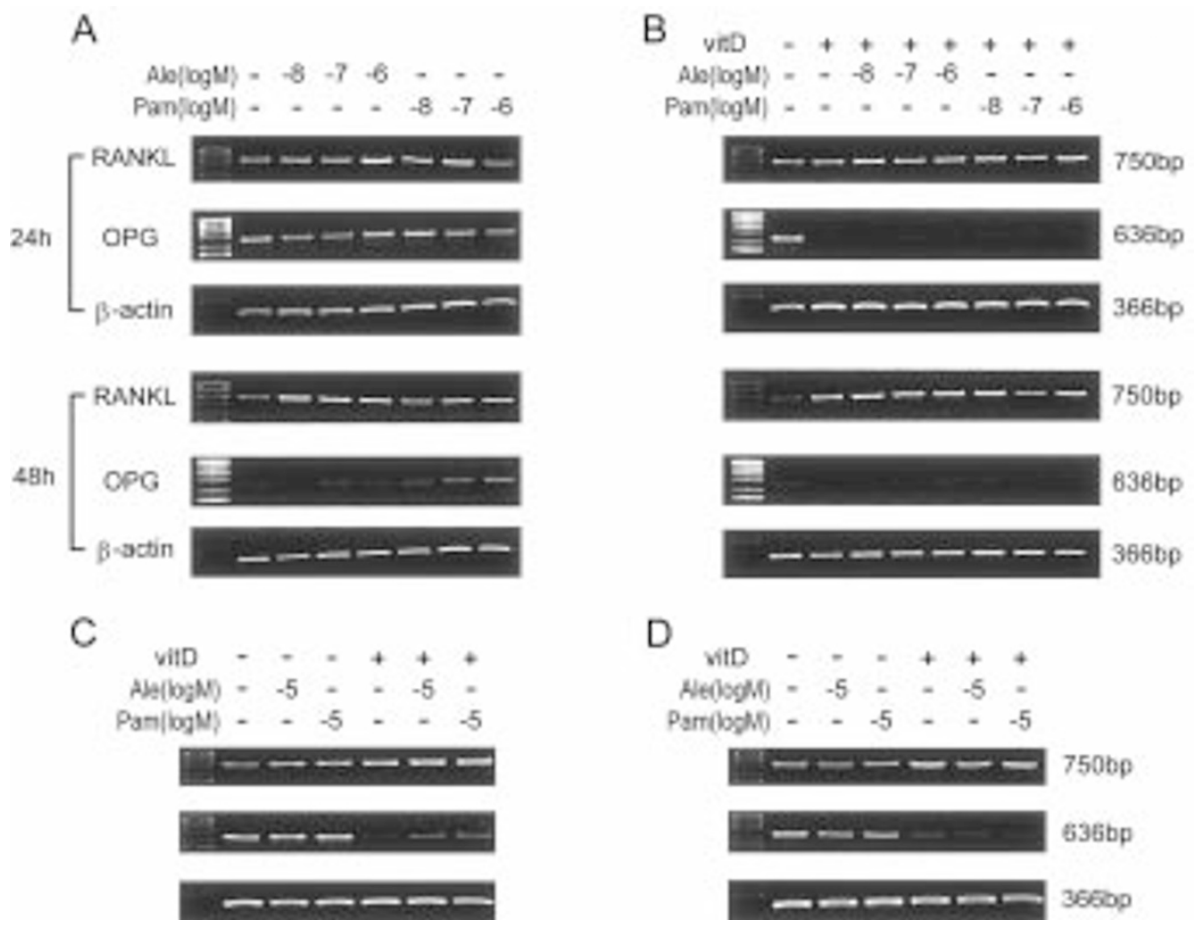

Figure 1. Effect of bisphosphonates on the RANKL and OPG mRNA expression. Mouse osteoblastic cells were exposed to $10^{-8} \sim 10^{-6} \mathrm{M}$ alendronate or pamidronate for 24 or $48 \mathrm{~h}$ in the presence $(\mathrm{B})$ or absence $(\mathrm{A})$ of $1,25-(\mathrm{OH})_{2} \mathrm{VitD}_{3}$. C, D) Mouse osteoblastic cells were cultured with $10^{-5} \mathrm{M}$ of alendronate or pamidronate in the presence of $1,25-(\mathrm{OH})_{2} \mathrm{VitD}_{3}$ for $24 \mathrm{~h}(\mathrm{C})$ or $48 \mathrm{~h}(\mathrm{D})$. Ale:alendronate, Pam: pamidronate.

(for $\mathrm{mVNR}$ and $\mathrm{mCTR}$ ), at $55^{\circ} \mathrm{C}$ (for mRANKL and mTRAP) or at $60^{\circ} \mathrm{C}$ (for $\mathrm{mOPG}$ and $\mathrm{m} \beta$-actin) for $30 \mathrm{~s}$, and extension at $72^{\circ} \mathrm{C}$ for $1 \mathrm{~min}$. All PCRs were within the exponential amplification range. The primer sequences are shown in Table I. PCR products were electrophoresed on a $1.2 \%$ agarose gel and visualized under the UV light after ethidium bromide staining. For semiquantitative estimation, the gel was analyzed with Quantity One (BIO-RAD. Hercules, CA, USA).

\section{Results and Discussion}

Alendronate and pamidronate, the nitrogen containing bisphosphonates, have been known to be effective against Pagets disease, osteoporosis, tumor-associated bone disease, and glucocorticoid-induced osteoporosis (Frijlink et al., 1979; Reid et al., 1994; Berenson et al., 1996; Black et al., 1996; Saag et al., 1999; Orwoll et al., 2000).

To investigate whether alendronate and pamidronate affect the mRNA expression of RANKL and OPG in osteoblasts, we performed semiquantitative RT-PCR by using total RNA from mouse osteoblastic cells treated with various concentrations of alendronate or pamidronate. Since the basal level of RANKL mRNA expression in primary osteoblastic cells was too low to be detected by northern blot analysis, we employed RT-PCR analysis instead. As shown in Figure 1A, neither alendronate nor pamidronate induced any consistent change in RANKL and OPG mRNA level after $24 \mathrm{~h}$. Unexpectedly, after 48 $\mathrm{h}$ treatment, both alendronate and pamidronate rather increased RANKL mRNA expression. OPG mRNA expression level was slightly increased only by $10^{-7}$ and $10^{-6} \mathrm{M}$ pamidronate. According to the previous reports, osteotropic agents modulate osteoclast formation through the regulation of the ratio of RANKL/OPG expression rather than increasing or decreasing RANKL and/or OPG alone (Hofbauer et al., 1999; Atkins et al., 2000; Hofbauer et al., 2000). The increase in the RANKL/OPG ratio means condition favoring increased osteoclast formation and vice versa. In the present study, the RANKL/OPG ratio, calculated from data obtained by densitometric analysis, was rather increased in all experimental groups except in the group of pamidronate treatment for $48 \mathrm{~h}$ (data not shown).

Next, we performed the same experiments in the presence of $1,25-(\mathrm{OH})_{2} \mathrm{VitD}_{3}$ to examine the effects of bisphosphonates under the osteoclastogenic environment. $1,25-(\mathrm{OH})_{2} \mathrm{VitD}_{3}$ is well known to effectively induce osteoclastogenesis in cocultures of mouse spleen cells and osteoblast-rich populations (Udagawa et al., 1989) and to increase RANKL expression and to decrease OPG expression (Horwood et al., 1998; Murakami et al., 1998; Yasuda et al., 1998). Consistent with the previous reports, $1,25-(\mathrm{OH})_{2} \mathrm{VitD}_{3}$ upregulated RANKL expression and downregulated OPG expression 
A

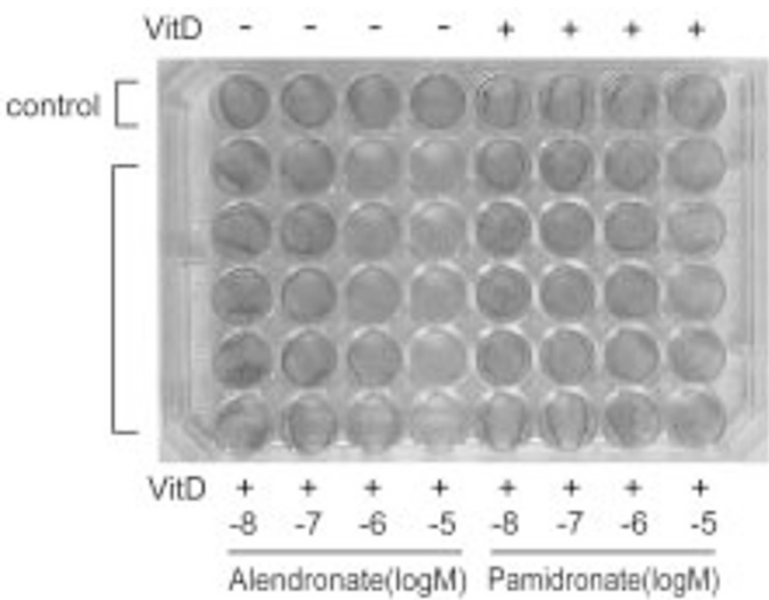

B

Control

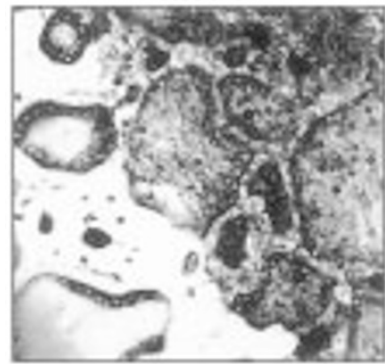

Alendronate

Pamidronate
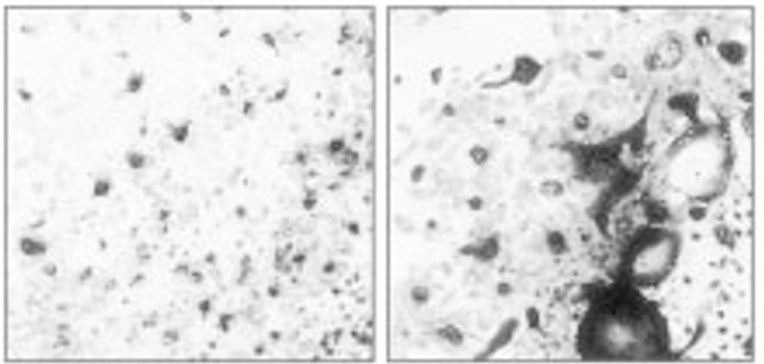

C

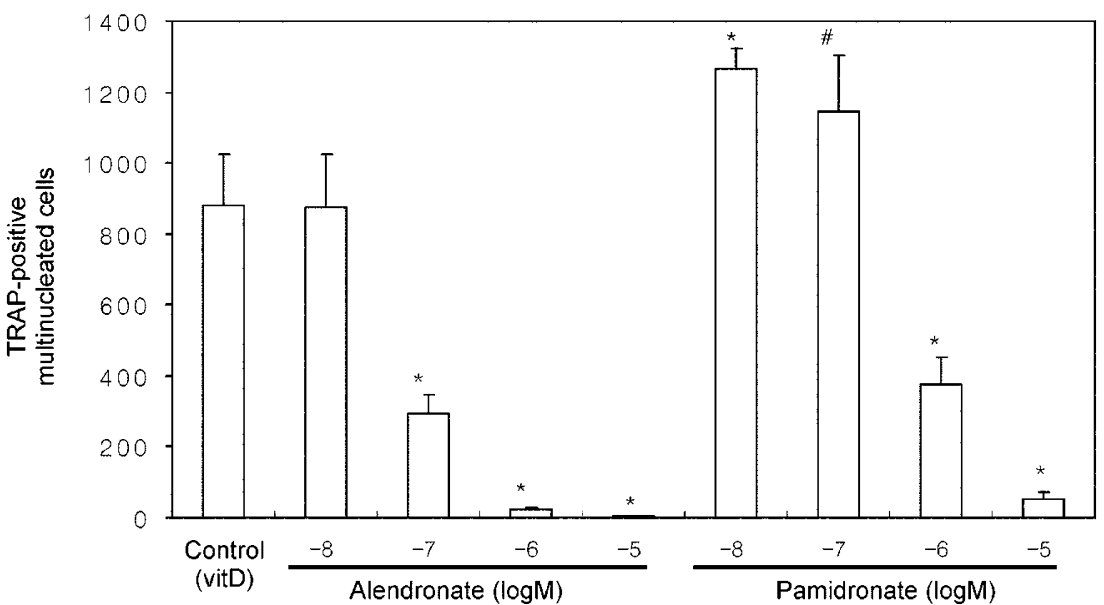

Figure 2. Effect of bisphosphonates on the osteoclast formation. Mouse osteoblastic cells $\left(7.5 \times 10^{3} \mathrm{cells} /\right.$ well) and bone marrow cells $\left(1.5 \times 10^{5} \mathrm{cells} / \mathrm{well}\right)$ were cocultured in the presence of $10 \mathrm{nM}$ of $1,25-(\mathrm{OH})_{2} \mathrm{VitD}$ for 6 days. Various concentrations of alendronate or pamidronate were added over the culture period. A) TRAP-stained 48-well culture plate. B) Osteoclast-like cells (OCLs) formed in the culture were identified by TRAP staining. Representative areas are shown here. Original magnification $\times 100$. C) The numbers of OCLs containing 3 or more nuclei were counted. Data represent mean $\pm S . D$. ( $n=5$ ) $\# p<0.05$, compared to control, ${ }^{*} p<0.01$, compared to control.

in mouse osteoblastic cells (Figure 1B) and increased RANKL/OPG ratio upto 10 folds. The addition of alendronate or pamidronate for $24 \mathrm{~h}$ did not affect the altered expression level of RANKL and OPG by 1,25$(\mathrm{OH})_{2} \mathrm{VitD}_{3}$. After $48 \mathrm{~h}$ treatment, bis-phosphonates still did not alter RANKL expression level. OPG expression, reduced by $1,25-(\mathrm{OH})_{2} \mathrm{VitD}_{3}$, was increased by bisphosphonates but was still lower than that of control. To rule out the possibility that the failure of bisphosphonates to alter the RANKL and OPG mRNA expression might be due to the low con-centration of the agents, we repeated experiment with $10^{-5} \mathrm{M}$ alendronate or pamidronate. As shown in Figure $1 \mathrm{C}$ and $\mathrm{D}$, higher concentration of alendronate and pamidronate 


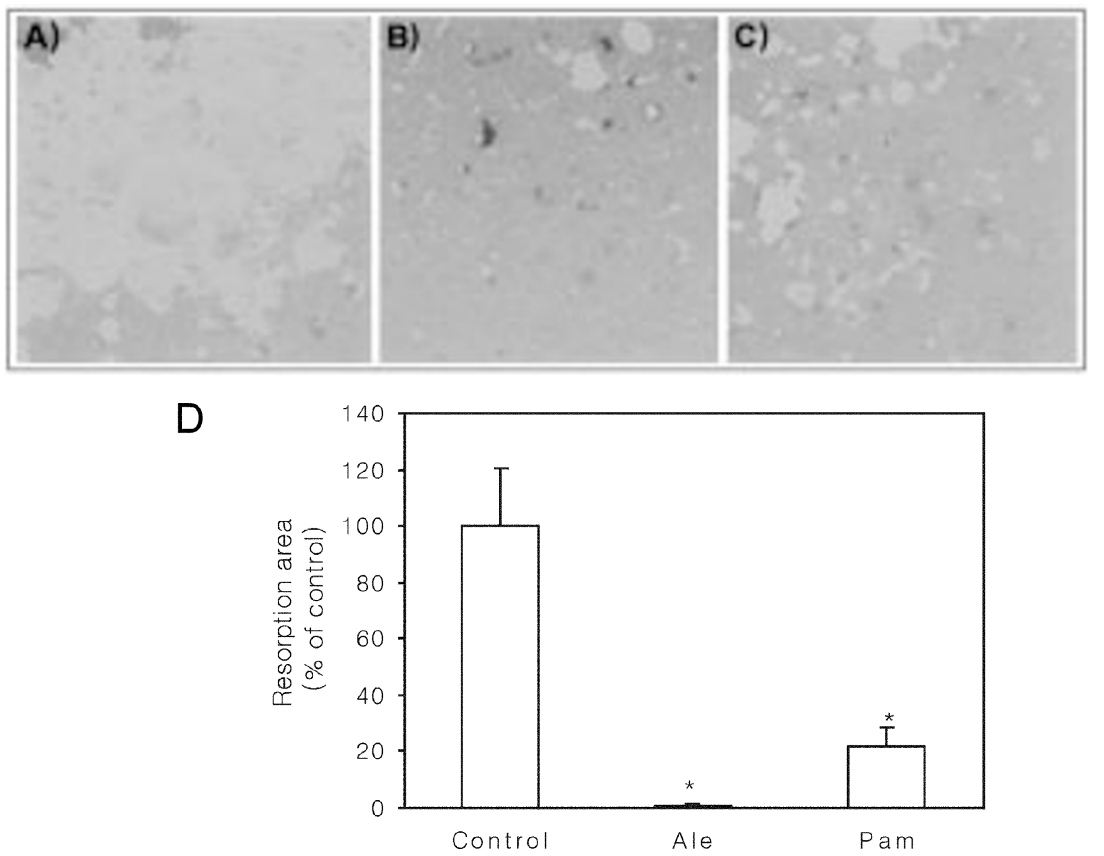

Figure 3. Effect of bisphosphonates on the bone resorption by osteoclasts. Mouse osteoblastic cells $\left(7.5 \times 10^{3}\right.$ cells/well) and bone marrow cells $\left(1.5 \times 10^{5}\right.$ cells/well) were cocultured in a 48-well plate coated with bone mineral-like apatite crystal $\left(\mathrm{OAAS}^{\mathrm{TM}}\right)$ in the presence of $10 \mathrm{nM}$ of $1,25-(\mathrm{OH})_{2} \mathrm{VitD} \mathrm{D}_{3}$ for 6 days and $10^{-5} \mathrm{M}$ alendronate or pamidronate was added over the culture period. At the end of the culture, cells were removed and resorption area was measured by using Global Lab image system. Representative areas are shown here. Original magnification $\times 40$. A) Control, B) Alendronate $\left.\left(10^{-5} \mathrm{M}\right), \mathrm{C}\right)$ Pamidronate $\left.\left(10^{-5} \mathrm{M}\right), \mathrm{D}\right)$ The areas resorbed by OCLs are plotted as percent of control. Data represent means \pm S.D. $(n=4){ }^{*}<0.01$, compared to control. Ale: alendronate, Pam: pamidronate

also failed to upregulate the OPG expression or downregualte RANKL expression irres-pective of the presence of $1,25-(\mathrm{OH})_{2} \mathrm{Vit}_{3}$. These results indicate that alendronate or pamidronate did not regulate RANKL and OPG expression in mouse os-teoblasts in favor of inhibition of osteoclastogenesis. To rule out the possibility that these results were due to the inactivity of these bisphosphonates in our experimental system, we confirmed the inhibitory effect of these compounds on in vitro osteoclastogenesis and os-teoclast function.

To examine the inhibitory effects of alendronate and pamidronate on the in vitro osteoclast formation, we cocultured mouse bone marrow cells with osteoblastic cells in the presence of $1,25-(\mathrm{OH})_{2} \mathrm{VitD}_{3}$ with various concentrations of alendronate or pamidronate. Both alendronate and pamidronate inhibited the osteoclast formation in a dose-dependent manner (Figure 2). The number of TRAP(+) OCLs were reduced by $10^{-7} \sim 10^{-5} \mathrm{M}$ alendronate. Pamidronate also decreased osteoclast formation at $10^{-6}$ and $10^{-5} \mathrm{M}$. Interestingly, $10^{-8}$ and $10^{-7} \mathrm{M}$ pamidronate increased the number of $\operatorname{TRAP}(+)$ OCLs, which appeared to be contradictory to the inhibitory effect of bisphosphonates. The majority of 1,25$(\mathrm{OH})_{2} \mathrm{VitD}_{3}$-induced multinucleated TRAP $(+)$ cells were OCLs containing more than 10 nuclei, which are thought to be more active than OCLs containing smaller numbers of nuclei (Figure 2B). In contrast, $\operatorname{TRAP}(+)$ OCLs formed in the presence of $10^{-8}$ and $10^{-7} \mathrm{M}$ pamidronate, are largely made up with OCLs containing only 3 or 4 nuclei, indicating that pamidronate at these concentrations might inhibit fusion of osteoclast precursors into large multinucleated cells (Figure 2B).

To further investigate the effect of bisphosphonates on

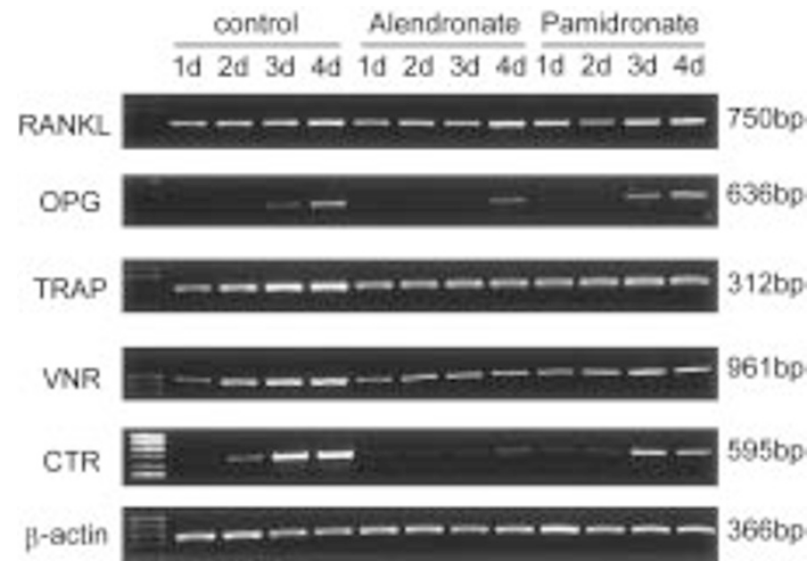

Figure 4. Effect of bisphosphonates on the mRNA expression of RANKL, $\mathrm{OPG}$, and osteoclast markers in cocultures. Mouse bone marrow cells $\left(3 \times 10^{6}\right.$ cells $)$ and osteoblastic cells $\left(1.5 \times 10^{4}\right.$ cells $)$ were cocultured in 60 $\mathrm{mm}$ dish in the presence of $10 \mathrm{nM}$ of $1,25-(\mathrm{OH})_{2} V_{i t D_{3}} \cdot 10^{-5} \mathrm{M}$ Alendronate or pamidronate was added over the culture period. After indicated culture periods, total RNA was isolated and used for semiquantitative RT-PCR. TRAP, tartrate-resistant acid phosphatase; VNR, vitronectin receptor; CTR, calcitonin receptor 
the in vitro osteoclast activity, we measured the area of bone mineral-like apatite crystal resorbed by OCLs. As shown in Figure 3, both alendronate and pamidronate reduced the area resorbed by OCLs. In this study, the reduction of resorption area by bisphosphonates seems to be attributable to the decrease in the number of OCLs rather than the direct effect on the resorption machinery, since both alendronate and pamidronate inhibited osteoclast formation almost completely at $10^{-5} \mathrm{M}$.

The coculture system used in this study has different microenvironment from the culture of osteoblasts alone in that the interactions between two cell population could affect each other. Thus, it needs to explore whether bisphosphonates regulate RANKL or OPG ex-pression in this coculture system. We performed semiquantitative RTPCR by using the total RNA from the cocultures treated with alendronate or pamidronate for the indicated times during coculture. In the presence of $1,25-(\mathrm{OH})_{2} \mathrm{VitD}_{3}$, the mRNA expression of os-teoclastic markers, such as TRAP, VNR, and CTR, were increased according to the differentiation (Figure 4). In cocultures treated with alendronate or pamidronate, however, the markers were hardly upregulated, consistent with the TRAP staining result. In control cul-ture, $1,25-(\mathrm{OH})_{2} \mathrm{VitD}_{3}$-induced RANKL mRNA ex-pression was maintained during the culture period, while suppression of OPG mRNA expression by $1,25-(\mathrm{OH})_{2} \mathrm{VitD}_{3}$ was relieved according to the progression of culture periods. Both alendronate and pamidronate failed to alter the mRNA expression level of RANKL and OPG over the culture period. These results show that the inhibition of osteoclast formation by alendronate and pamidronate is not associated with the regulation of RANKL or OPG mRNA expression.

Bisphosphonates manifest their anti-resorptive action via several mechanisms including direct effects on osteoclasts and indirect actions through osteoblasts. They have been suggested to inhibit differentiation, survival, and activity of osteoclast through osteoblastsecreted osteoclast-inhibiting factor, which has not yet been identified (Vitte et al., 1996; Yu et al., 1996). Recently, Mackie et al. reported that pamidronate reduced RANKL mRNA expression in UMR-106 osteosarcoma cell line after a 6-day culture, but did not alter OPG expression, which is different from our results (Mackie et al., 2001). The discrepancy might be attributed to the differences in the source of cells such as species and primary vs. cancer cells. Although our results demonstrated that bisphosphonates did not significantly affected RANKL and OPG mRNA levels, it could not be ruled out that they would modulate RANKL and OPG expression at the post-transcriptional level, necessitating further study at the protein level.

In conclusion, the present study showed that nitrogencontaining bisphosphonates, alendronate and pamid-ronate, did not alter the RANKL and OPG mRNA expression in favor of the inhibition of the osteoclast formation. Although alendronate and pamidronate in-hibited osteoclast formation and bone resorption in cocultures of mouse osteoblastic cells and bone marrow cells, these inhibitory effects did not appear to be linked to the regulation of RANKL and OPG mRNA expression. Taken together, it could be suggested that RANKL and OPG might not be the main target of bisphosphonates to inhibit bone resorption.

\section{Acknowledgements}

This work was supported by 2001 BK21 project for Medicine, Dentistry, and Pharmacy.

\section{References}

Atkins GJ, Haynes DR, Geary SM, Loric M, Crotti TN, Findlay DM. Coordinated cytokine expression by stromal and hematopoietic cells during human osteoclast formation. Bone 2000;26:653-56

Aubin JE, Bonnelye E. Osteoprotegerin and its ligand: A new paradigm for regulation of osteoclastogenesis and bone resorption. Osteoporos Int 2000;11:905-13

Berenson JR, Lichtenstein A, Porter L, Dimopoulos MA, Bordoni R, George S, Lipton A, Keller A, Ballester O, Kovacs MJ, Blacklock HA, Bell R, Simeone J, Reitsma DJ, Heffernan $M$, Seaman J, Knight RD. Efficacy of pamidronate in reducing skeletal events in patients with advanced multiple myeloma. Myeloma Aredia Study Group. N Engl J Med 1996;334:488-93

Black DM, Cummings SR, Karpf DB, Cauley JA, Thompson DE, Nevitt MC, Bauer DC, Genant HK, Haskell WL, Marcus R, Ott SM, Torner JC, Quandt SA, Reiss TF, Ensrud KE. Randomised trial of effect of alendronate on risk of fracture in women with existing vertebral fractures. Lancet 1996;348:1535-41

Fleisch, H. Bisphosphonates in bone disease: From the laboratory to the patient. 3rd Ed., 1997, Parthenon Pub. Group Inc, New York, NY

Frijlink WB, Bijvoet OL, te Velde J, Heynen G. Treatment of Paget's disease with (3-amino-1-hydroxypropylidene)-1,1bisphosphonate (A.P.D.). Lancet 1979;1:799-803

Hayashi S, Yamane T, Miyamoto A, Hemmi $H$, Tagaya $H$, Tanio Y, Kanda H, Yamazaki H, Kunisada T. Commitment and differentiation of stem cells to the osteoclast lineage. Biochem Cell Biol 1998;76:911-22

Hofbauer LC, Khosla S, Dunstan CR, Lacey DL, Boyle WJ, Riggs BL. The roles of osteoprotegerin and osteoprotegerin ligand in the paracrine regulation of bone resorption. $J$ Bone Miner Res 2000;15:2-12

Hofbauer LC. Osteoprotegerin ligand and osteoprotegerin: novel implications for osteoclast biology and bone metabolism. Eur J Endocrinol 1999;141:195-210

Horwood NJ, Elliott J, Martin TJ, Gillespie MT. Osteotropic agents regulate the expression of osteoclast differentiation factor and osteoprotegerin in osteoblastic stromal cells. 
Endocrinology 1998;139:4743-46.

Hughes DE, MacDonald BR, Russell RG, Gowen M. Inhibition of osteoclast-like cell formation by bisphosphonates in long-term cultures of human bone marrow. J Clin Invest 1989;83:1930-35

Hughes DE, Wright KR, Uy HL, Sasaki A, Yoneda T, Roodman GD, Mundy GR, Boyce BF. Bisphosphonates promote apoptosis in murine osteoclasts in vitro and in vivo. J Bone Miner Res 1995;10:1478-87

Jilka RL, Takahashi K, Munshi M, Williams DC, Roberson PK, Manolagas SC. Loss of estrogen upregulates osteoclastogenesis in the murine bone marrow: evidence for autonomy from factors released during bone resorption. J Clin Invest 1998;101:1942-50

Kim SR, Baek JH, Kim GS. Effect of high extracellular $\mathrm{Ca}^{2+}$ concentration on the formation of osteoclast-like cells and the functions of osteoblastic cells. J Dent Col 1998;22:569-85

Lacey DL, Timms E, Tan HL, Kelley MJ, Dunstan CR, Burgess T, Elliott R, Colombero A, Elliot G, Scully S, Hsu H, Sullivan J, Hawkins N, Davy E, Capparelli C, Eli A, Qian YX, Kaufman S, Sarosi I, Shalhoub V, Senaldi G, Guo J, Delaney J, Boyle WJ. Osteoprotegerin ligand is a cytokine that regulates osteoclast differentiation and activation. Cell 1998;93:165-76

Mackie PS, Fisher JL, Zhou H, Choong PF. Bisphosphonates regulate cell growth and gene expression in the UMR 106-01 clonal rat osteosarcoma cell line. Br J Cancer 2001;84:951-58

Murakami T, Yamamoto M, Ono K, Nishikawa M, Nagata N, Motoyoshi K, Akatsu T. Transforming growth factor-1 increases mRNA levels of osteoclastogenesis inhibitory factor in osteoblastic stromal cells and inhibits the survival of murine osteoclast-like cells. Biochem Biophys Res Commun 1998;252:747-52

Nishikawa M, Akatsu T, Katayama Y, Yasutomo Y, Kado S, Kugal N, Yamamoto M, Nagata N. Bisphosphonates act on osteoblastic cells and inhibit osteoclast formation in mouse marrow cultures. Bone 1996;18:9-14

Orwoll E, Ettinger M, Weiss S, Miller P, Kendler D, Graham J, Adami S, Weber K, Lorenc R, Pietschmann P, Vandormael K, Lombardi A. Alendronate for the treatment of osteoporosis in men. N Engl J Med 2000;343:604-10

Papapoulos, S. Bisphosphonates: Pharmacology and use in the treatment of osteoporosis. In Osteoporosis (Marcus, R., Feldman, D., and Kelsey, J., eds.), 1996, pp1209-34. Academic Press, San Diego, CA

Parfitt AM, Mundy GR, Roodman GD, Hughes DE, Boyce BF. A new model for the regulation of bone resorption, with particular reference to the effects of bisphosphonates. J Bone Miner Res 1996;11:150-59

Plotkin LI, Weinstein RS, Parfitt AM, Roberson PK, Manolagas SC, Bellido T. Prevention of osteocyte and osteoblast apoptosis by bisphosphonates and calcitonin. J Clin Invest 1999;104:1363-74.

Quinn JMW, Elliott J, Gillespie MT, Martin TJ. A combination of osteoclast differentiation factor and macrophage-colony stimulating factor is sufficient for both human and mouse osteoclast formation in vitro. Endocrinology 1998;139:4424-27

Reid IR, Wattie DJ, Evans MC, Gamble GD, Stapleton JP, Cornish J. Continuous therapy with pamidronate, a potent bisphosphonate, in postmenopausal osteoporosis. $\mathrm{J}$ Clin Endocrinol Metab 1994;79:1595-99

Rodan GA, Fleisch HA. Bisphosphonates: mechanisms of action. J Clin Invest 1996;97:2692-96

Roodman GD. Advances in bone biology: the osteoclast. End Rev 1996;17:308-32

Saag KG, Emkey R, Schintzer TJ, Brown JP, Hawkins F, Goemaere S, Thamsborg G, Liberman UA, Delmas PD, Malice MP, Czachur M, Daifotis A. Alendronate for the prevention and treatment of glucocorticoid-induced osteoporosis. N Engl J Med 1999;339:292-99

Sahni M, Guenthe, HL, Fleisch H, Collin P, Martin TJ. Bisphosphonates act on rat bone resorption through the mediation of osteoblasts. J Clin Invest 1993;91:2004-11

Simonet WS, Lacey DL, Dunstanm CR, Kelleym M, Chang MS, Luthy R, Nguyen HQ, Wooden S, Bennett L, Boone T, Shimomoto G, De. Rose. M. Osteoprotegerin: a novel secreted protein involved in the regulation of bone density. Cell 1997;89:303-19

Suda T, Nakamura I, Jimi E, Takahashi N. Regulation of osteoclast function. J Bone Miner Res 1997;12:869-79

Suda T, Takahashi N, Udagawa N, Jimi E, Gillespie MT, Martin TJ. Modulation of osteoclast differentiation and function by the new members of the tumor necrosis factor receptor and ligand families. Endocr Rev 1999;20:345-57

Takahashi N, Udagawa N, Suda T. A new member of tumor necrosis factor ligand family, ODF/OPGL/TRANCE/RANKL, regulates osteoclast differentiation and function. Biochem Biophys Res Commun 1999;256:449-55

Udagawa N, Takahashi N, Akatsu T, Sasaki T, Yamaguchi A, Kodama H, Martin TJ, Suda T. The bone marrow-derived stromal cell lines MC3T3-G2/PA6 and ST2 support osteoclastlike cell differentiation in cocultures with mouse spleen cells. Endocrinology 1989;125:1805-13

Vitte C, Fleisch H, Guenther HL. Bisphosphonates induce osteoblasts to secrete an inhibitor of osteoclast-mediated resorption. Endocrinology 1996;137:2324-33

Yasuda H, Shima N, Nakagawa N, Mochizuki S, Yano K, Fujise $\mathrm{N}$, Sato $\mathrm{Y}$, Goto $\mathrm{M}$, Yamaguchi K, Kuriyama M, Kanno T, Murakami A, Tsuda E, Morinaga T, Higashio K. Identity of osteoclastogenesis inhibitory factor (OCIF) and osteoprotegerin (OPG): a mechanism by which OPG/OCIF inhibits osteoclastogenesis in vitro. Endrocrinology 1998;139:1329-37

Yasuda H, Shima N, Nakagawa N, Yamaguchi K, Kinosaki M, Mochizuki S, Tomoyasu A, Yano K, Goto M, Murakami A, Tsuda E, Morinaga T, Higashio K, Udagawa N, Takahashi N, Suda T. Osteoclast differentiation factor is a ligand for osteoprotegerin/osteoclastogenesis-inhibitory factor and is identical to TRANCE/RANKL. Proc Natl Acad Sci USA 1998;95:3597-602

Yu X, Scholler J, Foged NT. Interaction between effects of parathyroid hormone and bisphosphonate on regulation of osteoclast activity by the osteoblast-like cell line UMR-106. Bone 1996;19:339-45 